\title{
Infectious Postpartum Sacroilitis: The Importance and Difficulty of Early Diagnosis
}

\author{
Sacroileíte Infecciosa do Pós-parto: A Importância e \\ Dificuldade do Diagnóstico Precoce
}

\author{
Emídio VALE-FERNANDES ${ }^{1}{ }^{1}$, Fedra RODRIGUES ${ }^{1}$, Carla MONTEIRO ${ }^{1}$, Luís CARVALHO ${ }^{1}$ \\ Acta Med Port 2016 Jul-Aug;29(7-8):484-487 - http://dx.doi.org/10.20344/amp.7062
}

\begin{abstract}
The sacroiliitis accounts for about $1.5 \%-10 \%$ of all cases of septic arthritis and it is strongly associated with gynaecological infections, pelvic trauma or drug abuse $(3.4 \%-12.8 \%$ of cases occur during the postpartum period). Early diagnosis is difficult because the symptoms are nonspecific in pregnancy and in the postpartum period, making the delay of treatment a serious risk of irreversible damage to the joint and development of post-infectious complications. The authors describe the case of a 37-year-old puerperal woman presented to hospital, weeks after urgent caesarean section, with endometritis, post-anesthetic epidural hematoma and secondary infectious postpartum sacroiliitis. The diagnosis of sacroiliac joints pathology during pregnancy and puerperium is challenging. The pathogenesis of infectious sacroiliitis results from local contamination by contiguous infection or hematogenous spread of bacterial infections. The prognosis is usually favorable and depends on early diagnosis and treatment.
\end{abstract}

Keywords: Arthritis, Infectious/diagnosis; Hematoma, Epidural, Spinal; Postpartum Period; Sacroiliac Joint.

\section{RESUMO}

A sacroileíte representa $1,5 \%-10 \%$ de todos os casos de artrite séptica e está fortemente associada a infecções ginecológicas, trauma pélvico e a abuso de drogas ( $3,4 \%$ - 12,8\% dos casos ocorrem durante o puerpério). O diagnóstico precoce é difícil, pois os sintomas são inespecíficos na gravidez e no puerpério, retardando o tratamento, podendo assim causar danos irreversíveis à articulação e desenvolvimento de complicações pós-infecciosas. Os autores descrevem o caso de uma puérpera de 37 anos que duas semanas após realização de cesariana urgente iniciou quadro de endometrite, hematoma epidural secundário a complicação anestésica e sacroileíte infecciosa secundária. O diagnóstico de patologia da articulação sacroilíaca durante a gravidez e puerpério constitui um desafio. A patogénese da artrite séptica resulta da contaminação local por infecção contígua ou da disseminação hematogénea. $O$ prognóstico da sacroileíte infecciosa do pós-parto é geralmente favorável e depende do diagnóstico e tratamento precoces.

Palavras-chave: Articulação Sacroilíaca; Artrite Infecciosa/diagnóstico; Hematoma Epidural Espinhal; Período Pós-Parto.

\section{INTRODUCTION}

The sacroilitis accounts for about $1.5 \%-10 \%$ of all cases of septic arthritis and it is strongly associated with gynaecological infections, pelvic trauma or drug abuse $(3.4 \%-12.8 \%$ of cases occur during the postpartum period) $\cdot{ }^{1-7} \mathrm{~A}$ review published in 2013 by Bart et al presents 20 cases of infectious postpartum sacroiliitis ${ }^{1}$ (including a review published by Almoujahed et al in 2003, of 15 cases). ${ }^{2}$ After that, Nair et al (2013), ${ }^{3}$ Park et al (2013), ${ }^{4}$ Shaikh et al (2014), ${ }^{5}$ Imagama et al $(2015)^{6}$ and Millwala et al (2015), 7 published another five cases. Nair et al reported a rare case of postpartum tuberculous sacroilitis, which has not been reported in the literature earlier (the patient completely recovered with antituberculous treatment) ${ }^{3}$ and Millwala et al described a woman who received several sessions of acupuncture treatment during her gestation at the site of her sacroiliac joint for sciatica, which developed biopsy-confirmed sacroiliitis with methicillin-sensitive Staphylococcus aureus during the immediate postpartum period. ${ }^{7}$ Table 1 shows the characteristics of cases of infectious postpartum sacroiliitis published in the literature since 1966 (search on PubMed/Medline with 'Postpartum period', 'Infectious sacroiliitis', 'Septic arthritis' and 'Septic sacroiliitis' - Medical Subject Headings [MeSH] terms). ${ }^{1-7}$
Considering its rather unspecific symptoms during pregnancy and puerperium, the establishment of an early diagnosis is difficult, making the delay of treatment a serious risk of irreversible damage to the joint and development of post-infectious complications. ${ }^{1,2,5,6}$

\section{CASE REPORT}

The authors describe the case of a 37-year-old puerperal woman, previously healthy, submitted to an uneventfully urgent caesarean delivery due to premature rupture of membranes (two previous caesareans), under spinal anesthesia, who began right back pain, irradiating to the right leg, and gait claudication two weeks after said procedure. On the emergence of hyperthermia, malaise, abdominal-pelvic pains, worsening of right low back pain and a remarkably raised $C$ reactive protein level of 250 $\mathrm{mg} / \mathrm{L}$ and leukocytosis with neutrophilia, a puerperal infection was diagnosed (cervix microbiological examination revealed methicillin-sensitive Staphylococcus aureus; postoperative wound showed no signs of inflammation), which was treated with amoxicillin/clavulanic acid (14 days), analgesia and uterotonic agents (apyrexia in 24 hours). Because of the worsening of the right low back pain, limited 
mobility and sensory changes of right buttock and thigh, a spine magnetic resonance imaging (MRI) was performed that revealed small anterior epidural blood collection (in subacute phase), from L3 to S2-S3, with close relationship of emerging L4-L5 roots. It was decided to start mid-term corticosteroid therapy, with improvement of pain complaints and functional limitation during hospitalization (completed home steroids cycle of 4 weeks). After completion of the steroids, there was further worsening of the right low back pain with de novo hyperthermia. Inpatient pelvic MRI showed large right buttock abscess (probably in the context of intramuscular medication), right sacroiliitis, multiple paravertebral muscles abscesses and arthritis of the L4-L5 joint (Fig. 1). A surgical drainage of the buttock abscess was performed, and the patient started intravenous therapy with ceftriaxone and vancomycin (four weeks) for secondary sacroiliitis (previous puerperal/epidural infection). Blood cultures in feverish peak were negative. The patient was discharged with significant improvement of complaints and completed domiciliary therapy with linezolid (over three weeks). The patient was followed up on the Chronic Pain consultation and also on Orthopedics, and was discharged about 1 year after delivery, with complete regression of the painful symptoms and significant regression of previous inflammatory/infectious processes.

\section{DISCUSSION}

The diagnosis of sacroiliac joints pathology during pregnancy and postpartum period is challenging (typical low back pain of this joints inflammatory process is very common in this female physiological period). ${ }^{1-11}$ The pathogenesis of infectious sacroiliitis results from either direct extension from a local infection or via hematogenous spread of bacterial infections (endocarditis, sinusitis, urinary tract infections or postpartum endometritis). 1,2,9-11 The concomitant diagnosis of post-epidural anesthesia hematoma in this patient also raises the possibility that this post-anesthetic complication may compete for the differential diagnosis of low back pain and for the infectious source of sacroiliitis. ${ }^{8}$ The frequency of septic sacroiliitis in pregnant and puerperal women suggests that during the pregnancy and the postpartum period there are local and systemic factors that decrease the sacroiliac

Table 1 - Characteristics of infectious postpartum sacroiliitis cases published in the literature between 1966 and $2015^{1-7}$

\begin{tabular}{|c|c|c|}
\hline Infectious postpartum sacroiliitis & Cases published in the literature, $n$ & This case report \\
\hline \multicolumn{3}{|c|}{ Demographic characteristics and risk factors } \\
\hline Average age [extremes] (years) & $28[17-40]$ & 37 \\
\hline Drug addiction & 3 & - \\
\hline Endocarditis & 2 & - \\
\hline Contiguous infection & 6 & Yes \\
\hline None & 16 & - \\
\hline \multicolumn{3}{|l|}{ Clinical presentation } \\
\hline Acute $(<7$ postpartum days) & 16 & - \\
\hline Subacute (> 7 postpartum days) & 9 & Yes \\
\hline Initial fever & 18 & Yes \\
\hline Buttock pain & 18 & Yes \\
\hline Inguinal or thigh pain & 6 & Yes \\
\hline Back pain & 6 & Yes \\
\hline \multicolumn{3}{|l|}{ Obstetrical context } \\
\hline Postpartum & 16 & Yes \\
\hline Post-abortion & 3 & - \\
\hline Current pregnancy & 7 & - \\
\hline \multicolumn{3}{|l|}{ Bacterial identification } \\
\hline Staphylococcus aureus & 7 & Yes \\
\hline $\begin{array}{l}\text { Streptococcus pyogenes } \\
\text { (Beta-hemolytic group A) }\end{array}$ & 4 & - \\
\hline $\begin{array}{l}\text { Streptococcus agalactiae } \\
\text { (group B) }\end{array}$ & 2 & - \\
\hline Streptococcus pneumonia & 2 & - \\
\hline Mycobacterium tuberculosis & 1 & \\
\hline Another Staphylococcus & 2 & - \\
\hline Not identified & 7 & - \\
\hline
\end{tabular}

Table adapted from the publication of G. Bart et al (2013) ${ }^{1}$

$\mathrm{n}$ : Number of cases published 

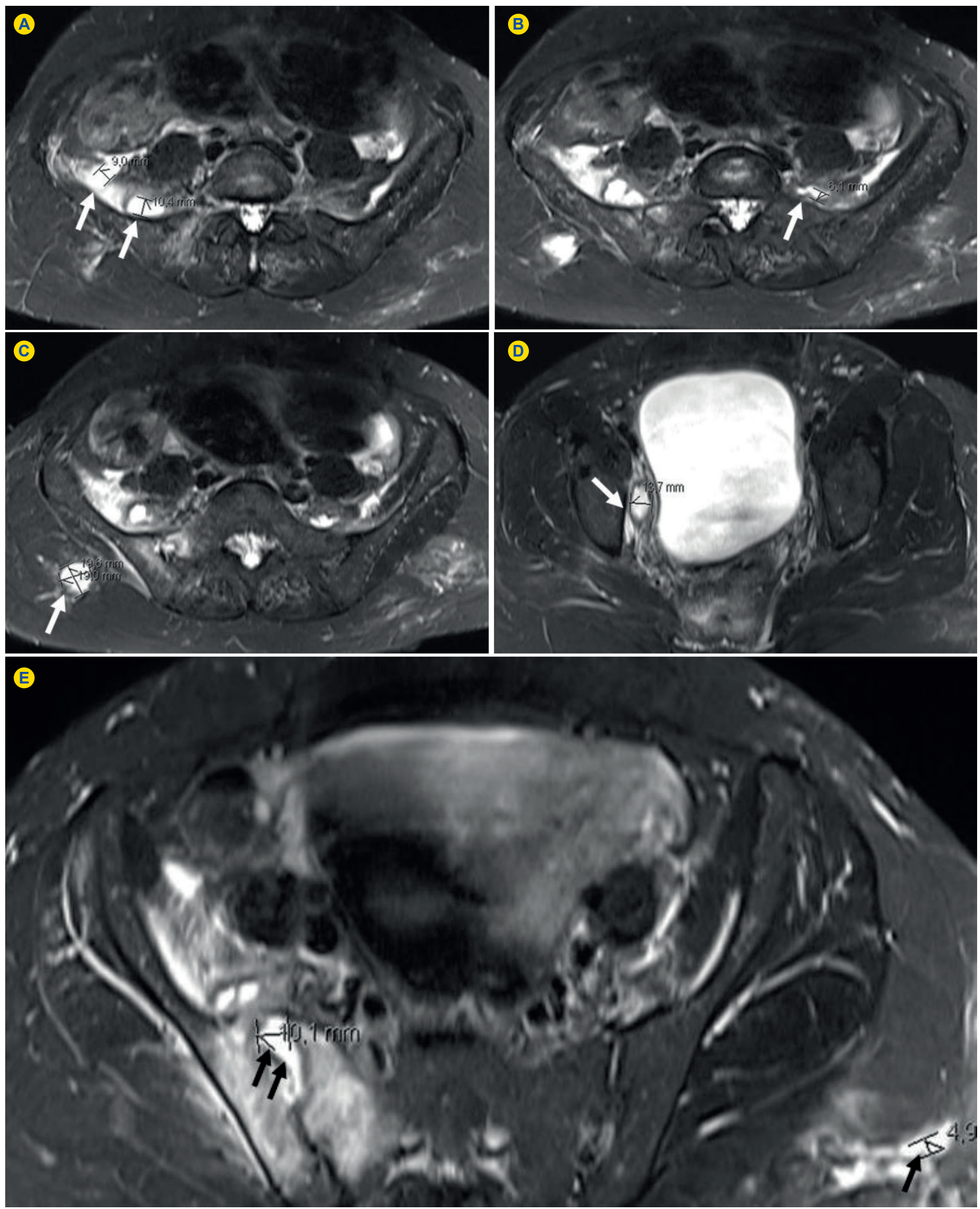

Figure 1 - Pelvic nuclear magnetic resonance (T2-TIRM weighted images). A: Liquid collections with $9 \mathrm{~mm}$ and $10 \mathrm{~mm}$ of greater thickness at the right psoas-iliac muscle with muscle fibers signal change (white arrows). B: Left iliac muscle signal change with liquid collection of about $6 \mathrm{~mm}$ thicker (white arrow). C: Liquid collection in the right buttock of about $20 \times 20 \mathrm{~mm}$, compared with probable abscess (white arrow). D: Liquid collection of about $13 \mathrm{~mm}$ of greater thickness extending from the right pelvic cavity up to the right shutter channel with pectineus and adductor magnus muscles signal change (white arrow). E: Signal change of the two bone components of the right sacroiliac join, with enlargement of the articulation and presence of intra-articular liquid collection with about $10 \mathrm{~mm}$ thick, that given the clinical context translates probable septic arthritis (double black arrows). Presence of small liquid collection of about $5 \mathrm{~mm}$ in the left buttock region (single black arrow). 
joint' resistance, such as changes in pressures due to growth of the pregnant uterus, relaxation of the pelvic ligaments, trauma of delivery, and the context of pregnancy-induced immunosuppression.,9-11 These changes may affect the microvasculature of the joint, leading to microscopic areas of injury on the joint surface, thus turning the periosteum more susceptible to bacterial invasion. ${ }^{7,11}$

By analysis of published postpartum sacroiliitis cases (Table 1), the most common form of clinical presentation is fever, associated with pain in the buttock, with possible limping gait, and acute onset (up to one week after delivery). ${ }^{1-11}$ In the present case report, the clinical subacute onset (two weeks) might be related to treatment with corticosteroids in the suspected post-anesthetic epidural hematoma.

The most frequently isolated organism is Staphylococcus aureus, ${ }^{1,6}$ most often methicillin-sensitive, but cases have been described of infections caused by Streptococcus spp., another Staphylococcus spp., ${ }^{1-11}$ and one case of infection by Mycobacterium tuberculosis was identified. ${ }^{3}$ Imagama et al (2014) described a case of infectious postpartum sacroiliitis caused by methicillin-resistant Staphylococcus aureus (MRSA). The incidence of community-acquired MRSA infection, which even occurs in young people without risk factors, has increased, and MRSA is one of the most alarming pathogenic bacteria. ${ }^{6}$

MRI is the exam with greater sensitivity to evaluate the affected joint and surrounding tissues and is particularly recommended during pregnancy and the postpartum period because of the absence of ionizing radiation. ${ }^{1,6}$

\section{REFERENCES}

1. Bart G, Plat M, Derouet N, Dernis E. Post-partum infectious sacroiliitis. Med Mal Infect. 2013;43:431-3.

2. Almoujahed MO, Khatib R, Baran J. Pregnancy-associated pyogenic sacroiliitis: case report and review. Infect Dis Obstet Gynecol. 2003;11:53-7.

3. Nair KR, Jayachandran R. Postpartum tuberculous sacroiliitis. Am J Orthop. 2013;42:E16-7.

4. Park YS, Owen AM, Adno AM, Marry J. Pyogenic sacroiliitis due to group A streptococcus following uncomplicated pregnancy and vaginal delivery. Case Rep Obstet Gynecol. 2013;2013:981474.

5. Shaikh M, Tahir H. Sacroilitis: an unusual cause for a common presentation. BMJ Case Rep. 2014;2014.

6. Imagama T, Tokushige A, Sakka A, Seki K, Taguchi T. Postpartum pyogenic sacroiliitis with methicillin-resistant Staphylococcus aureus
The recommended antibiotic treatment for infectious sacroiliitis in pregnancy and puerperium is similar to that used in other patients - a bi-drug intravenous scheme for 4 6 weeks. ${ }^{1}$ Rarely, it may be necessary a surgery intervention to drain any abscess in contiguity that do not respond to medical therapy. ${ }^{1}$ Whenever possible, prescription of antibiotics should be based on the antibiotic susceptibility of isolated specimens.

The prognosis is usually favorable and depends on early diagnosis and treatment. ${ }^{1-11}$

\section{ACKNOWLEDGEMENTS}

The authors are grateful for the cooperation of the Departments of Obstetrics and Gynaecology, General Surgery, Orthopedics, Neurosurgery, Anaesthesiology and Radiology of Hospital de Braga.

\section{PROTECTION OF HUMANS AND ANIMALS}

The authors declare that the procedures described in this article followed the regulations of their Institution' Clinical Research and Ethics Committee and the Helsinki Declaration of the World Medical Association.

\section{CONFLICTS OF INTEREST}

The authors declare there was no conflict of interest while conducting this work.

\section{SOURCES OF FUNDING}

The authors declare that this work was not subject to any financing.

in a healthy adult: A case report and review of the literature. Taiwan $J$ Obstet Gynecol. 2015;54:303-5.

7. Millwala F, Chen S, Tsaltskan V, Simon G. Acupuncture and postpartum pyogenic sacroiliitis: a case report. J Med Case Rep. 2015;9:193.

8. Mulvey JM. Postpartum septic sacroiliitis coincident with labour epidural analgesia. Anaesth Intensive Care. 2008;36:875-8.

9. Lau SM, Chou CT, Huang CM. Unilateral sacroiliitis as an unusual complication of acupuncture. Clin Rheumatol. 1998;17:357-8.

10. Haq I, Morris V. Post-partum septic sacroiliitis. Rheumatology. 2001;40:1191-2.

11. Moros ML, Rodrigo C, Villacampa A, Ruiz J, Lapresta C. Septic shock in pregnancy due to pyogenic sacroiliitis: a case report. J Med Case Rep. 2009;3:6505. 